\title{
Perbedaan kemampuan menggiring bola antara kelompok rangkaian bermain dan rangkaian latihan siswa
}

\author{
Erman Susanto*) \\ Sekolah Dasar Negeri 03 Lagan Hilir
}

\begin{tabular}{l}
\hline Article Info \\
\hline Article history: \\
Received April $24^{\text {th }}, 2021$ \\
Revised May $12^{\text {th }}, 2021$ \\
Accepted Jun $24^{\text {th }}, 2021$ \\
\hline
\end{tabular}

\section{Keyword:}

Rangkaian bermaian Rangkaian latihan Kemampuan menggiring bola

\begin{abstract}
Berdasarkan pengamatan peneliti terhadap fenomena yang terjadi pada siswa UPT SDN 03 Lagan Hilir Kecamatan Linggo Sari Baganti, bahwa kemampuan menggiring Bola cenderung rendah. Masalah inilah diduga disebabkan karena beberapa faktor, yang salah satunya adalah belum tepatnyya metode latihan yang diberikan pelatih. Penelitian ini bertujuan untuk menjelaskan pengaruh rangkaian bermain dan rangkaian latihan terhadap kemampuan menggiring bola di UPT SDN 03 Lagan Hilir Kecamatan Linggo Sari Baganti. Metode penelitian ini adalah metode eksperimen semu. Penelitian ini akan dilaksanakan pada Desember 2020. Adapun tempat penelitian adalah di lapangan UPT SDN 03 Lagan Hilir Kecamatan Linggo Sari Baganti. Populasi penelitian berjumlah 20 orang, teknik pengambilan sampel diambil dengan total sampling sehingga diperoleh sampel sebanyak 20 atlet. Data tes menggiring bola diambil dengan Tes menggiring bola. Teknik analisis data yaitu dengan rumus Uji t. Hasil analisis data menunjukkan bahwa: (1) terdapat bermaian memberikan pengaruh yang signifikan terhadap kemampuan menggiring bola. Peningkatan kemampuan menggiring bola adalah sebesar 7,73 , yaitu dari skor rata-rata 34,00 pada pre test menjadi 26,63 pada post test. (2) Rangkaian latihan memberikan pengaruh yang signifikan terhadap kemampuan menggiring bola. Adapaun pengaruh yang diberikan adalah sebesar 8,09 dari 34,05 saat prestes menjadi 25,96 saat post test. (3) Dengan thitung $(0,675)>$ ttabel $(2,228)$, hal ini berarti bahwa hipotesis penelitian tidakditerima. Dengan demikian dapat disimpulkan bahwa tidak terdapat perbedaan pengaruh rangkaian bermain dan rangkaian latihan terhadap kemampuan menggiring bola.
\end{abstract}

(C) 2021 The Authors. Published by IICET.

This is an open access article under the CC BY-NC-SA license (https://creativecommons.org/licenses/by-nc-sa/4.0)

\section{Corresponding Author:}

Erman Susanto,

Sekolah Dasar Negeri 03 Lagan Hilir

Email: ermansusanto@gmail.com

\section{Pendahuluan}

Pembangunan yang berkembang dewasa ini dilaksanakan bertujuan untuk mecapai masyarakat yang adil dan makmur dan berdasarkan Pancasila. Maka dari itu pembangaunan adalah peningkatan sumber daya manusia yang terampil, cerdas, sportifitas, serta sehat rohani dan jasmani dan guna mencerdaskan kehidupan bangsa Indonesia yang serasi selaras dan seimbang. Salah satu objek yang mendapatkan perhatian adalah olahraga. Hal ini sesuai dengan tujuan dari Keolahragaan Nasional yang tercantum dalam Undang-Undang RI No. 03 (2005) tentang Sistem Keolahragaan Nasional yang berbunyi: "Memelihara meningkatkan kesehatan dan kebugaran, prestasi, kualitas manusia, menanamkan nilai moral dan akhlak yang mulia, sportifitas, disiplin, mempererat serta mernbina persatuan dan kesetuan bangsa, martabat dan kehormatan bangsa". 
Uraian diatas tampaklah bahwa berbagai tujuan dan sasaran kegiatan olahraga Indonesia salah satunya pembinaan prestasi. Maksudnya yaitu bahwa kegiatan olahraga di Indonesia tidak hanya kesegaran jasmani atau rekreasi saja, melainkan harus berfikir juga kearah peningkatan prestasi olahraga agar dapat mengangkat harkat dan martabat bangsa ke kancah gelanggan Internasional.

Di sisi lain, dengan adanya kompetisi Persatuan Sepakbola Seluruh Indonesia (PSSI) sebagai induk organisasi olahraga sepakbola di Indonesia juga tidak lupa menetapkan pembinaan sepakbola yang berjenjang sesuai dengan sasaran kompetisi yang ada dan juga menetapkan pembinaan sepakbola dengan kerjasama melalui Departemen Pendidikan Nasional (Diknas) untuk mendirikan diklat-diklat pembinaan sepakbola yang ada di daerah serta diharapkan juga lahir pemain dari pembinaan tersebut.

Bentuk pembinaan yang di harapkan adalah pembinaan yang akan melahirkan pemain-pemain sepakbola atau atlet-atlet yang berprestasi. Tidak hanya memiliki skill yang bagus akan tetapi juga kondisi fisik yang baik. Pembinaan yang berjenjang dan terprogram akan mencetak pemain-pemain sepak bola yang menghasilkan dan membanggakan berupa prestasi atau kemenangan disetiap pertandingan dan kompetisi yang di ikuti.

Menyadari arti pentingnya kemapuan menggiring bola dalam sepakbola, maka penulis tertarik untuk melihat apakah bentuk rangkain latihan sendiri dan rangkaian bermaian dapat meningkatkan kemampuan menggiring bola, melalui penelitian yang berjudul "Perbedaan kemampuan menggiring bola antara kelompok rangkaian latihan dan rangkaian bermain dalam sepakbola pemain UPT SDN 03 Lagan Hilir Kecamatan Linggo Sari Baganti”.

\section{Metode}

Jenis penelitian ini adalah eksperimen semu. Populasi dalam penelitian ini adalah pemain UPT SDN 03 Lagan Hilir Kecamatan Linggo Sari Baganti. Jumlah sampel secara keseluruhan 20 orang dengan mengunakan cara ordinal matching pairing. Pemain tersebut dibagi menjadi 2 kelompok yang masing-masing kelompok terdiri dari 10 orang.

Berdasarkan jenis data yang diperlukan dalam penelitian ini adalah data primer yaitu data yang lansung dikumpulkan oleh peneliti dari sumbernya melalui tes dan pengukuran yaitu Pre-test dan Post-test tentang kemampuan menggiring bola dalam sepakbola. Sedangkan data sekunder dari penelitian ini diambil lansung dari pemain UPT SDN 03 Lagan Hilir Kecamatan Linggo Sari Baganti berkenaan dengan biodata dan lainlain.

Tes dilakukan untuk mengukur keterampilan menggiring bola dengan kaki dengan cepat disertai perubahan arah, (Nurhasan, 2001:161). Alat yang digunakan yang digunakan adalah Bola, Stop Watch, 6 buah rintangan (tongkat/lembing), Tiang bendera, dan Kapur. Penelitian dilakukan dengan menggunakan petunjuk pelaksanaan yang sudah ditentukan.

Gerakan yang diteliti pada penelitian ini akan dinyatakan gagal apabila: (1) Testee menggiring bola tidak sesuai dengan arah panah dan (2) Testee menggunakan anggota badan lainnya selain kaki, untuk menggiring bola.

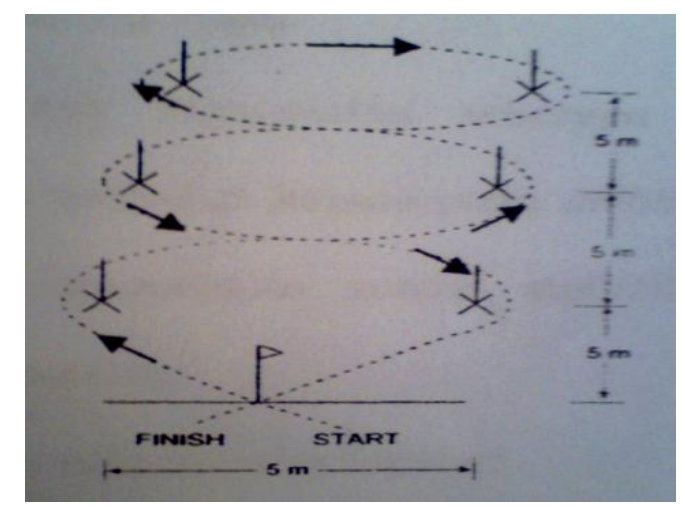

Sumber: Nurhasan (2001: 161)

Gambar 1. Tes Kemampuan Menggiring Bola

Data pada penelitian ini dianalisis menggunakan analisis statistik tes. Yaitu perbedaan hasil pre-test dengan pos-test yang dikutip dari Ispijardi (1988:57), dengan rumus pada gambar 2 : 


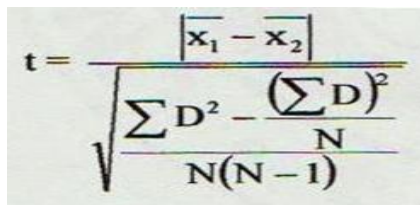

Gambar 2. Rumus Analisis Data

\section{Hasil dan Pembahasan}

Proses penelitian dilakukan selama 18 kali pertemuan. Dengan pertemuan pertama untuk tes awal, lalu diberi perlakuan sebayak 16 kali pertemuan. Hasil penelitian akan digambarkan sesuai dengan tujuan hipotesis yang diajukan sebelumnya.

\section{Deskripsi Data pengaruh latihan Rangkaian Bermain terhadap kemampuan Dribbling \\ Pre test}

Berdasarkan data penelitian untuk hasil kemampuan menggiring bola, Hasil tes awal (pre test) kemampuan menggiring bola kelompok A yaitu dengan latihan rangkaian bermain, dengan jumlah sampel 10 diperoleh skor tertinggi 38,6 untuk kemampuan menggiring bola, skor terendah 30,2, rata-rata (mean) 34 dari semua jumlah nilai sampel, median 33,2 dan, simpangan baku (SD) 2,761.

Berdasarkan perhitungan dapat dilihat bahwa: 2 orang atau (20\%) berada pada kelas interval 30,2-32,15, 4 orang atau (40\%) berada pada kelas interval 32,16-34,11, 1 orang atau (10\%) berada pada kelas interval 34,12$36,07,2$ orang atau (20\%) berada pada kelas interval 36,08-38,03, dan 1 orang atau (10\%) berada pada kelas interval 38,03-39,98. Untuk lebih jelasnya, distribusi frekuensi kemampuan menggiring bola

\section{Post Test}

Berdasarkan data penelitian untuk hasil kemampuan menggiring bola, Hasil tes akhir (post test) kemampuan menggiring bola kelompok A yaitu dengan kelompok rangkaian bermain, dengan jumlah sampel 10 diperoleh skor tertinggi 29,4 untuk kemampuan menggiring bola, skor terendah 25,1, rata-rata (mean) 26,63 dari semua jumlah nilai sampel, median 25,75 dan, simpangan baku (SD) 1,673.

Berdasarkan perhitungan dapat dilihat bahwa: 6 orang atau (60\%) berada pada kelas interval 25,1-26,1, 1 orang atau (10\%) berada pada kelas interval 26,2-27,2, 1 orang atau (10\%) berada pada kelas interval 27,328,3 , dan 2 orang atau (20\%) berada pada kelas interval 28,4-29,4.

\section{Deskripsi Data pengaruh kelompok Rangkaian latihan terhadap kemampuan Dribbling Pre test}

Berdasarkan data penelitian untuk hasil kemampuan menggiring bola, Hasil tes awal (pre test) kemampuan menggiring bola kelompok A yaitu dengan kelompok rangkaian latihan, dengan jumlah sampel 10 diperoleh skor tertinggi 37,7 untuk kemampuan menggiring bola, skor terendah 30,5, rata-rata (mean) 34,05 dari semua jumlah nilai sampel, median 33,35 dan, simpangan baku (SD) 2,650.

Berdasarkan perhitungan dapat dilihat bahwa: 2 orang atau (20\%) berada pada kelas interval 30,5-32,17, 4 orang atau (40\%) berada pada kelas interval 32,18-33,85, 0 orang atau ( $0 \%$ ) berada pada kelas interval 33,86$35,53,2$ orang atau (20\%) berada pada kelas interval 35,54-37,21, dan 2 orang atau (20\%) berada pada kelas interval 37,22-38,89.

\section{Post Test}

Berdasarkan data penelitian untuk kemampuan menggiring bola pada Pos Test, Selanjutnya hasil tes akhir (post test) diperoleh skor tertinggi untuk kemampuan menggirirng bola 30,3, skor terendah menggiring bola 21,8, rata-rata (mean) 25,96, median 25,95 dan, simpangan baku (SD) 2,572.

Berdasarkan perhitungan dapat dilihat bahwa: 2 orang atau (20\%) berada pada kelas interval 21,80-23,77, 3 orang atau (30\%) berada pada kelas interval $23,78-25,75,3$ orang atau (30\%) berada pada kelas interval $25,76-$ 27,73, 1 orang atau (10\%) berada pada kelas interval 27,74-29,71, dan 1 orang atau (10\%) berada pada kelas interval 29,72-31,69.

\section{Pegujian Persyaratan Analisis}

Hipotesis penelitian ini diuji dengan menggunakan analisis Uji t. Sebelum dilakukan analisis uji $t$ terlebih dahulu dilakukan uji normalitas dan uji homogenitas yaitu untuk mengetahui apakah data homogen dan berasal dari populasi yang berdistribusi normal atau tidak. Uji normalitas data post test dianalisis dengan statistik uji Lilifours, dengan taraf signifikansi yang digunakan sebagai dasar menolak ataupun menerima keputusan normal atau tidaknya suatu distribusi data adalah $\alpha>0,05$. 
Uji Normalitas

Dari hasil pengolahan data uji Normalitas dengan Uji Lilifours diperoleh angka normalitas distribusi data seperti pada Tabel berikut :

Tabel 6. Rangkuman Hasil Pengujian Normalitas

\begin{tabular}{lcccc}
\hline Data & N & Lo & Ltabel & Ket \\
Kelompok A & 12 & 0,1257 & 0,2580 & Normal \\
Kelompok B & 12 & 0,1740 & 0,2580 & Normal \\
\hline
\end{tabular}

Tabel di atas menunjukkan bahwa hasil pengujian untuk data kelompok A adalah 0,1257 dengan probabilitas (sig.) 0,2580. Dengan $\alpha>0,05$, maka dapat disimpulkan bahwa data berdistribusi normal. Hasil pengujian untuk data kelompok B adalah 0,1291 dengan probabilitas (sig.) 0,2580. Dengan $\alpha>0,05$, maka dapat disimpulkan bahwa data berdistribusi normal.

Berdasarkan uraian di atas semua variabel datanya berdistribusi normal. Berdasarkan kriteria Jika $\mathbf{L}_{\text {Observasi (Lo) lebih kecil atau sama dengan }} \mathbf{L}_{\text {tabel }}(\mathrm{Lt}$ ) berarti data populasi berdistribusi normal, sebaliknya jika $\mathbf{L}_{\text {Observasĩ }}(\mathrm{Lo})$ lebih besar dari $\mathbf{L}_{\text {tabel }}(\mathrm{Lt})$ berarti data populasi berdistribusi tidak normal, karena masing-masing variabel probabilitasnya memenuhi kriteria Lo < LTabel. Hal ini dapat dikatakan bahwa data masing-masing tersebar secara normal atau populasi dari data sampel diambil berdistribusi normal.

\section{Uji Homogenitas}

Uji homogenitas dilakukan untuk melihat apakah data penelitian memiliki varians yang sama (homogen) atau tidak.

$$
F_{\text {hitung }}=\frac{\text { VarianBesar }}{\text { VarianKecil }} \quad F_{\text {hitung }}=\frac{6,614}{2,800} \quad F_{\text {hitung }}=2,362
$$

Hasil analisis di atas terlihat bahwa nilai $\mathrm{F}_{\text {hitung }}$ adalah 2,362 sedangkan $\mathrm{F}$ tabel dengan menggunakan derajat kebebasan (n1-1), (n2-1) dan dengan taraf signifikansi probability pada setiap variabel lebih besar dari 0,05 , jadi didapat $\mathrm{F}$ tabel $=3,18$ dengan demikian berarti bahwa data penelitian ini adalah homogen, ini dikarenakan $2,36<3,18$. sehingga dapat dilanjutkan untuk analisis pengujian hipotesis.

\section{Pengujian Hipotesis}

Setelah uji persyaratan analisis dilakukan dan ternyata semua data tiap variabel penelitian memenuhi persyaratan untuk dilakukan pengujian statistik lebih lanjut, maka selanjutnya dilaksanakan pengujian hipotesis. Dalam penelitian ini ada tiga hipotesis penelitian, yaitu: (1) Terdapat pengaruh latihan rangkaian bermain yang berarti terhadap kemampuan menggiring bola. (2) Terdapat pengaruh rangkaian latihan yang berarti tehadap kemampuan menggiring bola. (3) Terdapat perbedaan berarti terhadap kemampuan menggirirng bola antara tangkaian bermain dan rangkaian latihan. Berikut ini disajikan hasil pengujian terhadap ketiga hipotesis penelitian yang telah diajukan di atas.

\section{Terdapat pengaruh rangkaian bermaian yang berarti terhadap kemampuan menggiring bola}

Uji statistik yang digunakan adalah t-test yaitu melihat pengaruh rerata hitung dalam satu kelompok yang sama pada taraf signifikan 0,05 . Hasil tes awal (pre test) kemampuan menggiring bola kelompok A yaitu dengan rangkaian bermain, dengan jumlah sampel 10 diperoleh skor tertinggi 38,6 untuk menggirirng bola, skor terendah 30,2 untuk kemampuan untuk menggirirng bola, rata-rata (mean) 34 dari semua jumlah nilai sampel, median 33,2 dan, simpangan baku (SD) 2,761. Selanjutnya hasil tes akhir kemampuan menggiring bola setelah 16 kali perlakuan (post test) diperoleh skor tertinggi 29,4, skor terendah 25,1, rata-rata (mean) 26,63, median 25,75 dan, simpangan baku (SD) 1,673.

Berdasarkan tabel di atas dapat dilihat bahwa $t_{\text {hitung }}(9,767)>t_{\text {tabel }}(2,228)$. Hal ini berarti bahwa hipotesis penelitian dapat diterima. Dengan demikian dapat disimpulkan bahwa rangkaian bermaian memberikan pengaruh yang signifikan terhadap kemampuan menggiring bola. Peningkatan kemampuan menggiring bola adalah sebesar 7,73, yaitu dari skor rata-rata 34,00 pada pre test menjadi 26,63 pada post test.

\section{Terdapat pengaruh rangkaian latihan terhadap kemampuan menggiring bola}

Uji statistik yang digunakan adalah t-test yaitu melihat pengaruh rerata hitung dalam satu kelompok yang sama pada taraf signifikan 0,05. Hasil tes awal (pre test) kemampuan menggiring bola kelompok B yaitu dengan rangkaian latihan, dengan jumlah sampel 10 diperoleh skor tertinggi kemampuan menggiring bola 37,7 , skor terendah kemampuan menggiring bola 30,5, rata-rata (mean) 34,05, median 33,35 dan, simpangan 
baku (SD) 2,650. Selanjutnya hasil tes akhir (post test) diperoleh skor tertinggi untuk kemampuan menggiring bola 30,3, skor terendah kemampuan menggiring bola 21,8, rata-rata (mean) 25,96, median 25,95 dan, simpangan baku (SD) 2,572.

Berdasarkan tabel di atas dapat dilihat bahwa $t_{\text {hitung }}(12,51)>t_{\text {tabel }}(2,228)$. Hal ini berarti bahwa hipotesis penelitian dapat tidak diterima. Dengan demikian dapat disimpulkan bahwa rangkaian latihan memberikan pengaruh yang signifikan terhadap kemampuan menggiring bola. Adapaun pengaruh yang diberikan adalah sebesar 8,09 dari 34,05 saat prestes menjadi 25,96 saat post test setelah diberikan perlakukan.

Terdapat perbedaan berarti terhadap kemampuan menggiring bola antara rangkaian bermain dan rangkaian latihan Uji statistik yang digunakan adalah t-test yaitu melihat pengaruh rerata hitung dalam satu kelompok yang sama pada taraf signifikan 0,05. Adapun hasil tes akhir (post test) kelompok A diperoleh skor tertinggi 29,4, skor terendah 25,1, rata-rata (mean) 26,63, median 25,75 dan, simpangan baku (SD) 1,673, sedangkan hasil tes akhir (post test) kelompok B diperoleh skor tertinggi 30,3, skor terendah kemampuan menggiring bola 21,8, rata-rata (mean) 25,96, median 25,95 dan, simpangan baku (SD) 2,572.

Berdasarkan tabel dapat dilihat bahwa $t_{\text {hitung }}(0,675)>t_{a b e l}(2,228)$. Hal ini berarti bahwa hipotesis penelitian tidakditerima. Dengan demikian dapat disimpulkan bahwa tidak terdapat perbedaan pengaruh rangkaian bermain dan rangkaian latihan terhadap kemampuan menggiring bola. Dan dikarnakan rata-rata (mean) rangkaian latihan lebih kecil dibandingkan rata-rata (mean) rangkaian bermain yaitu 25,96 <26,63, maka dalam penelitian ini juga menerima hipotesis yang mengatakan bahwa rangkaian bermain lebih baik dari rangkaian latihan, hipotesis ditolak.

\section{Pembahasan}

Dalam usaha meningkatkan kemampuan menggring bola maka diberikan latihan. Dalam hal ini latihan yang diberikan adalah dengan menggunakan rangkaian bermain dan rangkaian latihan. Dari penggunaan kedua metode ini akan dilihat apakah ada perbedaan terhadap kemampuan menggiring bola.

Dalam pelaksanaan penelitian untuk mendapatkan data, pertama kali dilakukan tes awal. Tes awal ini bertujuan untuk melihat kemampuan menggiirng bola dan mengelompokkan sampel menjadi dua kelompok yang seimbang, yang nantinya di bagi untuk menentukan perlakuan dengan rangkaian bermaian dan rangkaian latihan. Setiap pertemuan perlakuan, sebelum dipisahkan kedua kelompok melakukan pemanasan bersama, sehingga akhirnya diharapkan penelitian ini dapat melahirkan kesimpulan yang tepat dan sesuai dengan data yang diperoleh.

Untuk itu perlu kiranya pengkajian tentang metodologi dan kajian teori dari suatu penelitian. Pengetahuan yang diperoleh melalui pendekatan ilmiah dan dibuat berdasarkan teori tertentu secara sistematis dan dilakukan sesuai dengan langkah-langkah atau prosedur yang benar dengan demikian hasil penelitian ini dapat diterima kebenarannya.

Terdapat pengaruh kelompok rangkaian latihan terhadap kemampuan menggiring bola pada Siswa UPT SDN 03 Lagan Hilir Kecamatan Linggo Sari Baganti.

Uji statistik yang digunakan adalah t-test yaitu melihat pengaruh rerata hitung dalam satu kelompok yang sama pada taraf signifikan 0,05. Hasil tes awal (pre test) kemampuan menggiring bola kelompok A yaitu dengan rangkaian bermain, dengan jumlah sampel 10 diperoleh skor tertinggi 38,6 untuk menggirirng bola, skor terendah 30,2 untuk kemampuan untuk menggiring bola, rata-rata (mean) 34 dari semua jumlah nilai sampel, median 33,2 dan, simpangan baku (SD) 2,761. Selanjutnya hasil tes akhir kemampuan menggiring bola setelah 16 kali perlakuan (post test) diperoleh skor tertinggi 29,4, skor terendah 25,1, rata-rata (mean) 26,63, median 25,75 dan, simpangan baku (SD) 1,673. Adapun Hasil pengujian Hipotesis di sajikan dalam tabel berikut ini:

Berdasarkan data dilihat bahwa $t_{\text {hitung }}(9,767)>t_{\text {tabel }}(2,228)$. Hal ini berarti bahwa hipotesis penelitian dapat diterima. Dengan demikian dapat disimpulkan bahwa rangkaian bermaian memberikan pengaruh yang signifikan terhadap kemampuan menggiring bola. Peningkatan kemampuan menggiring bola adalah sebesar 7,73, yaitu dari skor rata-rata 34,00 pada pre test menjadi 26,63 pada post test.

Terdapat pengaruh rangkaian bermain terhadap kemampuan menggiring bola pada Siswa UPT SDN 03 Lagan Hilir Kecamatan Lingoo Sari Baganti

Uji statistik yang digunakan adalah t-test yaitu melihat pengaruh rerata hitung dalam satu kelompok yang sama pada taraf signifikan 0,05 . Hasil tes awal (pre test) kemampuan menggiring bola kelompok B yaitu dengan rangkaian latihan, dengan jumlah sampel 10 diperoleh skor tertinggi kemampuan menggiring bola 37,7, skor terendah kemampuan menggiring bola 30,5, rata-rata (mean) 34,05, median 33,35 dan, simpangan baku (SD) 2,650. Selanjutnya hasil tes akhir (post test) diperoleh skor tertinggi untuk kemampuan menggiring 
bola 30,3, skor terendah kemampuan menggiring bola 21,8, rata-rata (mean) 25,96, median 25,95 dan, simpangan baku (SD) 2,572.

Berdasarkan data di atas dapat dilihat bahwa $t_{\text {hitung }}(12,51)>t_{\text {tabel }}(2,228)$. Hal ini berarti bahwa hipotesis penelitian dapat tidak diterima. Dengan demikian dapat disimpulkan bahwa rangkaian latihan memberikan pengaruh yang signifikan terhadap kemampuan menggirirng bola. Adapaun pengaruh yang diberikan adalah sebesar 8,09 dari 34,05 saat prestes menjadi 25,96 saat post test setelah diberikan perlakukan.

Terdapat perbedaan kemampuan menggiring bola antara kelompok rangkaian latihan dengan rangkaian bermain pada Siswa UPT SDN 03 Lagan Hilir Kecamatan Linggo Sari Baganti

Uji statistik yang digunakan adalah t-test yaitu melihat pengaruh rerata hitung dalam satu kelompok yang sama pada taraf signifikan 0,05. Adapun hasil tes akhir (post test) kelompok A diperoleh skor tertinggi 29,4, skor terendah 25,1, rata-rata (mean) 26,63, median 25,75 dan, simpangan baku (SD) 1,673, sedangkan hasil tes akhir (post test) kelompok B diperoleh skor tertinggi 30,3, skor terendah kemampuan menggiring bola 21,8, rata-rata (mean) 25,96, median 25,95 dan, simpangan baku (SD) 2,572.

Dapat dilihat bahwa $t_{\text {hitung }}(0,675)>\mathrm{tt}_{\text {abel }}(2,228)$. Hal ini berarti bahwa hipotesis penelitian tidakditerima. Dengan demikian dapat disimpulkan bahwa tidak terdapat perbedaan pengaruh rangkaian bermain dan rangkaian latihan terhadap kemampuan menggiring bola. Dan dikarnakan rata-rata (mean) rangkaian latihan lebih kecil dibandingkan rata-rata (mean) rangkaian bermain yaitu 25,96 <26,63, maka dalam penelitian ini juga menerima hipotesis yang mengatakan bahwa rangkaian bermain lebih baik dari rangkaian latihan, hipotesis ditolak.

\section{Simpulan}

Berdasarkan analisis data dan pembahasan yang telah dipaparkan terdahulu, maka dapat dikemukakan beberapa kesimpulan sebagai berikut: 1) Rangkaian bermaian memberikan pengaruh yang signifikan terhadap kemampuan menggiring bola. Peningkatan kemampuan menggiring bola adalah sebesar 7,73, yaitu dari skor rata-rata 34,00 pada pre test menjadi 26,63 pada post test; 2) Rangkaian latihan memberikan pengaruh yang signifikan terhadap kemampuan menggirirng bola. Adapaun pengaruh yang diberikan adalah sebesar 8,09 dari 34,05 saat prestes menjadi 25,96 saat post test. Dengan $t_{\text {hitung }}(0,675)>t_{\text {abel }}(2,228)$, hal ini berarti bahwa hipotesis penelitian tidakditerima. Dengan demikian dapat disimpulkan bahwa tidak terdapat perbedaan pengaruh rangkaian bermain dan rangkaian latihan terhadap kemampuan menggiring bola.

\section{Referensi}

Arsil. (2009). TesPengukuran danEvaluasi. Padang : Fakultas Ilmu Keolahragaan UNP.

Bompa, Tudor. O. (1999). Theory and Methodology of Training, The Key to Atletik Performance. Dubuge, Low: Kendal/Hunt Publishing Company. Terjemahan oleh Sarwono. Surabaya: Program Studi Ilmu Kesehatan Olahraga. Fakultas Pasca Sarjana Universitas Airlangga.

Darwis, Ratinus. (1999). Sepak Bola. Padang: FIK UNP.

Depdikbud, (1999). Psikologi Pendidikan. Jakarta: Depdikbud.

Hadi, Sutrisno. (2000). Statistik II. Yogyakarta : Andi.

Hadi, Sutrisno. (1990). Methodologhy Reseach. Yogyakarta, Andi, Offset.

Harsono. (1988). Coaching Dan Aspek-Aspek Psikologis Dalam Coaching. Jakarta: P2LPTK.

Nurhasan. (2001). Tes dan Pengukuran Dalam Pendidikan Jasmani. Jakarta Pusat: Direktorat Jenderal Olahraga.

Sajoto. M. (1988). Pengaruh latihan Pliometrik Bagi Pemain Berkecepatan Gerak Tinggi dan Kecepatan Gerak Rendah terhadap Hasil Tendangan Bola. Semarang : FPOK IKI

Syafruddin. (2011). Dasar-Dasar Kepelatihan Olahraga. Padang: FPOK.

Soejono, (1994). Olahraga dan Umur. Jakarta: Fakultas Kedokteran Universitas Indonesia.

Sudjana. (1996). Metode Statistika. Bandung: Tarsito.

Tim Sepakbola, FIKUNP.(2005). Sepakbola. Padang: Fakultas Ilmu Keolahragaan Universitas Negeri Padang. Undang-Undang Republik Indonesia Nomor 3 Tahun (2005), Jakarta: Depdiknas.

UNP, (2009). Buku Pedoman Penulisan Skripsi/TA, Padang. UNP

Yusuf. (2005). Metodologi Penelitian. Padang: UNP Press. 